\title{
Impact of Frontline Demonstration on Adoption of Improved Practices of Sunflower (Helinathus annuuss L.)
}

\author{
Shyamrao Kulkarni*, Renuka Biradar, Aravind Rathod and Prakash Sharanappa
}

Agriculture Extension Education Centre, Lingsugur-584122, Karnataka, India

*Corresponding author

\begin{tabular}{|l|}
\hline Ke y w o r d s \\
$\begin{array}{l}\text { Sunflower, FLD, } \\
\text { Technology, } \\
\text { Production }\end{array}$ \\
\hline Article Info \\
\hline $\begin{array}{l}\text { Accepted: } \\
18 \text { August } 2018 \\
\text { Available Online: } \\
\text { 10 September } 2018\end{array}$ \\
\hline
\end{tabular}

\section{A B S T R A C T}

Front line demonstration (FLD) is an appropriate means for demonstration as well as transfer of improved agricultural innovations to the farming community. Under centrally sponsored scheme on oilseed production technology under NMOOP scheme, AEEC, Lingsugur has conducted 32 front line demonstrations in farmer's fields during 2017-18 over an area of 12.8 ha on sunflower production technology to transfer the latest technologies among the farmers of Lingsugur taluka of Raichur district. The overall yield trend in FLD ranged from 785 to $1095 \mathrm{~kg} / \mathrm{ha}$ with an average of $950 \mathrm{~kg} / \mathrm{ha}$ which recorded 20.42 per cent higher yield than the farmers practice plot. Obviously, this can be attributed to improved technology as well as improved varieties. The yield levels were considerably low under local practices because of considerable variations in the extent of adoption of recommended package of practices depending upon the amount of risk involved in terms of cost, convenience, skill and knowledge about the concerned practice. The productivity was better over local practice under demonstrations. Hence, sunflower production technology have a broad scope for increasing the area and production at each and every level i.e., Farmers, State and National level.

\section{Introduction}

Sunflower is an important versatile oilseed crop which can be grown in any season of the year and it is rich in polyunsaturated fatty acid (PUFA) as well as high vitamin E content. In India, it is cultivated over an area of about 10.01 lakh hectares with a production of 4.96 lakh tonnes and productivity of $765 \mathrm{~kg}$ per hectare (Anon., 2016). The cultivation of sunflower is largely confined to southern parts of the country comprising the states of Karnataka, Maharashtra, Tamil Nadu and Andhra Pradesh. Karnataka is the leading sunflower producing state grown over an area of 4.22 lakh ha with production of 255.6 lakh tonnes and average productivity of $639 \mathrm{~kg}$ per ha which is lower than the national average $(765 \mathrm{~kg} / \mathrm{ha})$. At present, the oilseeds production in India is not meeting the domestic demands and now dependent on imports. The continuous increase in import of oilseed is a matter of great concern today. A wide gap exists in sunflower production with the use of available techniques and its actual application by the farmers and the higher incidence of pest attack leads to further reduction in yield, reflected through poor yield 
of sunflower crop on farmer's field. There is a tremendous opportunity for increasing the productivity of sunflower crop by adopting the improved technologies. To demonstrate the scientific cultivation of sunflower front line demonstrations should be laid out at farmer's field. The basic objective of FLDs is to demonstrate the proven technology at farmer's field (Verma et al., 2014).

The extent of adoption of improved agricultural technologies is a crucial aspect under innovation diffusion process and the most important for enhancing agricultural production at a faster rate. Large number of technologies evolved in the field of agriculture is not being accepted and adopted to its fullest extent by the farmers. The gap between recommendations made by the scientists and actual use by farmers is frequently encountered.

With the start of technology mission on oilseeds, frontline demonstration on oilseed crops using new crop production technology was started with the objectives of showing the production potential of the new technologies under real farm situation over the locally cultivated oilseed crops. The main objective of FLD is to demonstrate the crop production technologies and management practices in the farmers' fields under different agro-climatic regions and farming situations. The Agriculture Extension Education Centre has followed the concept of FLD in true spirit and conducted large number of demonstrations in different villages of Raichur district under NMOOP project.

\section{Materials and Methods}

The study was conducted at AEEC, Lingsugur in Raichur district in Karnataka state in farmers' fields during 2017 - 18 with objective to popularize improved technologies for productivity enhancement of sunflower through FLDs. Thirty two FLDs were conducted in farmer's field. To diffuse sunflower productivity enhancement technologies on campus and off campus trainings were conducted. Then improved practices were demonstrated with the following technologies

Improved hybrid- RSFH-130

Seed treatment with PSB $(500 \mathrm{~g})$, Azospirillum (500 g) and Trichoderma (5 g per $\mathrm{kg}$ of seeds)

Balanced nutrient application (FYM 8 t/ha, 90 $\mathrm{kg} \mathrm{N}, 90 \mathrm{~kg} \mathrm{P}_{2} \mathrm{O}_{5}, 60 \mathrm{~kg} \mathrm{~K}_{2} \mathrm{O}, 100 \mathrm{~kg}$ gypsum)

Integrated pest management (Timely spray of insecticides)

In check plot, farmers were applied in their regular practices (local variety, $45 \mathrm{Kg} \mathrm{N}$ and 40-60 $\mathrm{kg} \mathrm{P}_{2} \mathrm{O}_{5}$ ). The sunflower crop was sown during Kharif 2017-18 under irrigation condition. The crop was harvested at maturity stage. For the study, technology gap, extension gap and technology index were calculated as suggested by Samui et al., (2000).

Technology gap $=$ Potential yield Demonstration yield

Extension gap $=$ Demonstration yield Farmers yield

Technology index $(\%)=($ Potential yield Technology/Potential yield) $* 100$

\section{Results and Discussion}

The data were subjected to analysis, technology gap, extension gap and technology index were calculated as per the formula and economic analysis was done as per procedure and data were presented in the table 1 and 2 . 
Table.1 Grain yield of sunflower, technology gap, extension gap and technology index as influenced by improved practices

\begin{tabular}{|c|c|c|c|c|c|c|}
\hline \multirow{2}{*}{$\begin{array}{c}\text { Farmer } \\
\text { No. }\end{array}$} & \multicolumn{2}{|c|}{ Yield (Kg/ha) } & \multirow{2}{*}{$\begin{array}{l}\text { \% increase in yield } \\
\text { in FLD over FP }\end{array}$} & \multirow{2}{*}{$\begin{array}{c}\text { Technology } \\
\text { gap } \\
\text { (Kg/ha) }\end{array}$} & \multirow{2}{*}{$\begin{array}{c}\text { Extension } \\
\text { gap } \\
\text { (Kg/ha) }\end{array}$} & \multirow{2}{*}{$\begin{array}{l}\text { Technolog. } \\
\text { index }(\%)\end{array}$} \\
\hline & FLD & FP & & & & \\
\hline 1 & 850 & 685 & 24.09 & 150 & 165 & 15.00 \\
\hline 2 & 795 & 778 & 2.19 & 205 & 17 & 20.50 \\
\hline 3 & 1065 & 890 & 19.66 & -65 & 175 & -6.50 \\
\hline 4 & 785 & 695 & 12.95 & 215 & 90 & 21.50 \\
\hline 5 & 865 & 775 & 11.61 & 135 & 90 & 13.50 \\
\hline 6 & 915 & 756 & 21.03 & 85 & 159 & 8.50 \\
\hline 7 & 885 & 725 & 22.07 & 115 & 160 & 11.50 \\
\hline 8 & 950 & 755 & 25.83 & 50 & 195 & 5.00 \\
\hline 9 & 950 & 795 & 19.50 & 50 & 155 & 5.00 \\
\hline 10 & 1085 & 785 & 38.22 & -85 & 300 & -8.50 \\
\hline 11 & 995 & 855 & 16.37 & 5 & 140 & 0.50 \\
\hline 12 & 1050 & 775 & 35.48 & -50 & 275 & -5.00 \\
\hline 13 & 935 & 825 & 13.33 & 65 & 110 & 6.50 \\
\hline 14 & 950 & 785 & 21.02 & 50 & 165 & 5.00 \\
\hline 15 & 1020 & 765 & 33.33 & -20 & 255 & -2.00 \\
\hline 16 & 985 & 775 & 27.10 & 15 & 210 & 1.50 \\
\hline 17 & 975 & 850 & 14.71 & 25 & 125 & 2.50 \\
\hline 18 & 1095 & 825 & 32.73 & -95 & 270 & -9.50 \\
\hline 19 & 1085 & 865 & 25.43 & -85 & 220 & -8.50 \\
\hline 20 & 825 & 756 & 9.13 & 175 & 69 & 17.50 \\
\hline 21 & 875 & 825 & 6.06 & 125 & 50 & 12.50 \\
\hline 22 & 1025 & 795 & 28.93 & -25 & 230 & -2.50 \\
\hline 23 & 895 & 725 & 23.45 & 105 & 170 & 10.50 \\
\hline 24 & 975 & 775 & 25.81 & 25 & 200 & 2.50 \\
\hline 25 & 925 & 815 & 13.50 & 75 & 110 & 7.50 \\
\hline 26 & 865 & 785 & 10.19 & 135 & 80 & 13.50 \\
\hline 27 & 950 & 825 & 15.15 & 50 & 125 & 5.00 \\
\hline 28 & 885 & 865 & 2.31 & 115 & 20 & 11.50 \\
\hline 29 & 1075 & 825 & 30.30 & -75 & 250 & -7.50 \\
\hline 30 & 998 & 725 & 37.66 & 2 & 273 & 0.20 \\
\hline 31 & 965 & 745 & 29.53 & 35 & 220 & 3.50 \\
\hline 32 & 895 & 815 & 9.82 & 105 & 80 & 10.50 \\
\hline Average & 950 & 789 & 20.42 & 50 & 161 & 5.04 \\
\hline
\end{tabular}

Table.2 Economic analysis of sunflower demonstration

\begin{tabular}{|l|c|c|c|c|c|c|c|c|}
\hline \multirow{2}{*}{ Sl. No } & \multicolumn{2}{|c|}{ Cost of cultivation (Rs/ha) } & \multicolumn{2}{|c|}{ Gross returns (Rs/ha) } & \multicolumn{2}{|c|}{ Net returns (Rs/ha) } & \multicolumn{2}{|c|}{ B:C } \\
\cline { 2 - 11 } & FLD & FP & FLD & FP & FLD & FP & FLD & FP \\
\hline A verage & 13500 & 12200 & 26590 & 22081 & 13090 & 9881 & 1.97 & 1.81 \\
\hline
\end{tabular}


The overall yield trend in FLD ranged from 785 to $1095 \mathrm{~kg} / \mathrm{ha}$ with an average of 950 $\mathrm{kg} / \mathrm{ha}$ which recorded 20.42 per cent higher yield than the farmers practice plot. The higher yield of sunflower in FLD was mainly attributed to the adoption of improved technologies. Sunflower variety RSFH- 130 is potential yielder than local control and having moderate resistance to pests. Seed treatment with bio-inputs enabled to mobalise nutrients from native soil nutrients. Seed treatment with Trichoderma helped the crop to resist against diseases. The technology gap in the demonstration yield over potential yield was $50 \mathrm{~kg}$ per ha. The technological gap may be attributed to the dissimilarity in the soil fertility status and weather conditions. The extension gap of $161 \mathrm{~kg}$ per ha was noticed. This emphasized the need to educate the farmers through various means for the adoption of improved agricultural technologies to reverse this trend of wide extension gap. More and more use of latest production technologies with high yielding variety will subsequently change this alarming trend of galloping extension gap. The new technologies will eventually lead to the farmers to discontinue the old technology and to adopt new technology. The technology index shows the feasibility of the evolved technology at the farmer's fields and lower value of technology index more is the feasibility of the technology. In this demonstration noticed 5.04 per cent technologies index, which indicates proper adoption of improved technologies. Similar results were also recorded by Vikram et al., (2018) and Rupesh (2015) in sunflower, Anuja et al., (2014) in different oilseeds crops, Balai et al., (2012) in rapeseed mustard and Berjesha et al., (2013) in Brassica.

The inputs and outputs prices of commodities prevailed during the study demonstrations were taken for calculating gross return, cost of cultivation, net return and benefit cost ratio (Table 2). The cultivation of sunflower with improved technologies gave higher net return of Rs 13090/ha as compared to farmer's practices (Rs 9881/ha). The benefit cost ratio of sunflower in FLD was 1.97. This may be due to attributed higher yields obtained under improved technologies compared to local check.

The study has shown that the FLD programme was found useful in enhancing the knowledge and adoption level of farmers in various aspects of sunflower production technologies. FLD practices created great awareness and motivated the other farmers to adopt appropriate sunflower production technologies. The area of high yielding hybrid of sunflower has increased which will spread in the taluk including the adjoining area. The selection of critical input and participatory approach in planning and conducting the demonstration definitely help in the transfer of technology to the farmers.

\section{References}

Anonymous, 2016. Package of Practices, UAS, Raihcur.pp-159

Anuj Kumar Singh, Kinjulck C. Singh, Y.P. Singh, D.K. Singh, 2014. Impact of Frontline Demonstration on Adoption of Improved Practices of Oilseed Crops. Indian Res. J. Ext. Edu. 14 (3): 75-77.

Balai, C. M., Meena, R.P., Meena, B. L. and Bairwa R. K. 2012. Impact of Front Line Demonstration on RapeseedMustard Yield Improvement. Indian Res.J.Ext.Edu., 12 (2):115.

Berjesh Ajrawat, A Manu Parmar and Mahital Jamwal, 2013. Impact of front line demonstration of oilseed crops in improved technology transfer. Journal of Oilseed Brassica, 4(2): 96-97.

Meena, M. L. and Singh, D. 2013. Frontline demonstration for boosting the oilseeds production in Rajasthan: A case study in Pali. J. Oilseeds Res. 30(1):51-54. 
Rupesh Kumar Arora, 2015. Performance of Front Line Demonstrations on Sunflower (Helianthus annuus L.) in Ambala District, Haryana, India. American International Journal of Research in Formal, Applied \& Natural Sciences, 9(1): 33-35.

Samui, S.K., Maitra, S., Roy, D.K., Mandal, A.K. and Saha, D. 2000. Evaluation of Front Line demonstration on groundnut. J. Indian Soc. Coastal Agric. Res., 18(2):180-183.

Shenoi, P.V., 2003. Oilseed Production, Processing and Trade: A Policy Framework, Department of Economics
Analysis and Research; NABARD, Mumbai.

Verma, R. K., Dayanand, Rathore, R. S., Mehta, S. M. and Singh, M. 2014. Yield and gap analysis of wheat productivity through frontline demonstrations in Jhunjhunu district of Rajasthan. Ann. Agric. Res. New Series., 35(1):79-82.

Vikram Bharati, U.K. Singh, A.K. Paswan and M.N. Ansari, 2018. Performance of FLD Intervention on Yield of Sunflower (Helianthus annus L.) in Bihar, India. Int.J.Curr.Microbiol. App.Sci (2018) 7(3): 2878-2881.

\section{How to cite this article:}

Shyamrao Kulkarni, Renuka Biradar, Aravind Rathod and Prakash Sharanappa. 2018. Impact of Frontline Demonstration on Adoption of Improved Practices of Sunflower (Helinathus annuuss L.). Int.J.Curr.Microbiol.App.Sci. 7(09): 2511-2515.

doi: https://doi.org/10.20546/ijcmas.2018.709.311 